\title{
Genetic parameters for milk production and persistency in the Iranian Holstein population by the multitrait random regression model
}

\author{
Khabat Kheirabadi' and Sadegh Alijani ${ }^{2}$ \\ ${ }^{1}$ Animal Science Department, Khuzestan Ramin Agricultural \& Natural Resources University, Ahvaz, Khuzestan, Iran, \\ ${ }^{2}$ Department of Animal Science, University of Tabriz, Tabriz, Iran
}

\begin{abstract}
For genetic dissection of milk, fat, and protein production traits in the Iranian primiparous Holstein dairy cattle, records of these traits were analysed using a multitrait random regression test-day model. Data set included 763505 test-day records from 88204 cows calving since 1993. The (co)variance components were estimated by Bayesian method. The obtained results indicated that as in case of genetic correlations within traits, genetic correlations between traits decrease as days in milk (DIM) got further apart. The strength of the correlations decreased with increasing DIM, especially between milk and fat. Heritability estimates for 305-d milk, fat, and protein yields were $0.31,0.29$, and 0.29 , respectively. Heritabilities of test-day milk, fat, and protein yields for selected DIM were higher in the end than at the beginning or the middle of lactation. Heritabilities for persistency ranged from 0.02 to 0.24 and were generally highest for protein yield $(0.05$ to 0.24$)$ and lowest for fat yield $(0.02$ to 0.17$)$, with milk yield having intermediate values ( 0.06 to 0.22$)$. Genetic correlations between persistency measures and $305-\mathrm{d}$ production were higher for protein and milk yield than for fat yield. The genetic correlation of the same persistency measures between milk and fat yields averaged 0.76 , and between milk and protein yields averaged 0.82 .
\end{abstract}

Keywords: genetic evaluation, persistency, random regression, test-day milk yields

Abbreviations: DIM: days in milk, RRM: random regression test-day model, TD: test day

Archiv Tierzucht 57 (2014) 12, 1-12

doi: $10.7482 / 0003-9438-57-012$
Received: 19 August 2013

Accepted: 14 April 2014 Online: 23 May 2014

Corresponding author:

Khabat Kheirabadi, email: kheirabadi89@ms.tabrizu.ac.ir or kheirabadikh@gmail.com

Animal Science Department, Khuzestan Ramin Agricultural \& Natural Resources University, P.O. Box: 63517-73637, Ahvaz, Khuzestan, Iran

() 2014 by the authors; licensee Leibniz Institute for Farm Animal Biology (FBN), Dummerstorf, Germany. This is an Open Access article distributed under the terms and conditions of the Creative Commons Attribution 3.0 License (http://creativecommons.org/licenses/by/3.0/). 


\section{Introduction}

Dairy cows produce a lot of milk, but a more important goal of those who milk cows is to make a profit. A profitable dairy cow holds a high production level for a long time. The key factors determining the amount of total yield during a lactation period are peak yield, persistency and lactation length (Muir 2004). Persistency of lactation usually refers to the rate of decline in production after the peak of lactation. There is an inverse relationship between the rate of decline and lactation persistency (Togashi \& Lin 2004). Improved persistency of lactation can contribute to reducing the cost of the production system because lactation persistency is associated with feeding and health costs, reproductive performance, resistance to disease and the return from milk considering a 305-d production cycle (Dekkers et al. 1998, Harder et al. 2006, Sölkner \& Fuchs 1987). Dekkers et al. (1998) argued that cows with greater lactation persistency are more profitable than average cows when yield and lactation persistency are correlated. Therefore, it makes economic sense to investigate the genetic aspects of the lactation curve to improve persistency, as enhancing persistency could promote efficient and economical milk production. However, persistency should not be achieved at the expense of total lactation milk, as persistency is highly affected by lactation milk (Togashi \& Lin 2004). Jamrozik et al. (1997) expressed that, genetic evaluations with the use of random regression test-day model (RRM) not only improves the accuracy but can also evaluate persistency because the estimated breeding value for various parts of the lactation can be calculated. Gengler (1996) provided a review of many common definitions of persistency of lactation yields. Swalve \& Gengler (1999) sorted the persistency measures into 4 categories:

1) measures derived from the parameters of the lactation curve

2) those based on rations between total, partial and daily yields

3) those based on variation of test-day (TD) yields and

4) those derived from the RRM.

Jamrozik et al. (1997) compared three measures of persistency derived from parameters of lactation curves using a TD model and found that genetic correlations with lactation milk yield were all $>0.1$. Jakobsen et al. (2002) studied five different persistency measures using RRM and showed that the estimated genetic correlations with 305-d lactation yield ranged from 0.00 to 0.47 for milk, -0.30 to 0.10 for fat, and -0.20 to 0.53 for protein. In their study the estimated heritabilities ranged from 0.09 to $0.24,0.10$ to 0.31 and 0.07 to 0.19 for milk, fat and protein yield respectively.

Single-trait analysis, ignoring information on selective treatment of cows with different (genetic potential for) milk yield, would lead to biased genetic parameters, which in turn, would result in inappropriate predictions based on multi-trait national selection indexes (Kadarmideen et al. 2003). Therefore, the objectives of this research were as follows: a) to estimate the genetic parameters for milk production traits by a multitrait RRM; and b) to estimate the genetic and environmental parameters of different persistency measures and comparison of them. 


\section{Material and methods}

\section{Data}

The analysis was based on 3175207 TD milk production records of first parity of Iranian Holstein dairy cattle, calving between April 1987 and September 2010. Test-day observations before $\mathrm{d} 5$ and after $\mathrm{d} 305$ were deleted. Milk production records were included if there were at least 5 valid monthly tests, the first and last monthly test were $<60$ and $>250$ days in milk (DIM) respectively and all the consecutive tests were $\geq 15 \mathrm{~d}$ interval each. At least 10 cows per herd $\times$ year of calving were required. Cows were also omitted if whose sires had less than 10 daughters or ages at first calving were below 21 mo or above 46 mo.

Edited data consisted of 763505 records for TD milk, fat, and protein yield, produced by 88204 primiparous Iranian Holstein cows with known sire. Daily records for milk yield, fat percentages, and protein percentages were in the ranges 1 to $70 \mathrm{~kg}, 1.5$ to $9 \%$ and 1 to $7 \%$ respectively. Cows were assigned to 1 of 24 subclasses for age-season of calving. Four seasons of calving (winter, summer, fall and spring) and six classes for age at calving $(<26 \mathrm{mo}$, 26 to 27,28 to 29,30 to 31,32 to 33 , and $>33 \mathrm{mo}$ ) were defined. A full description of the data used is given in Table 1. Distribution of records across DIM for data set is presented in Figure 1. Even at the very end of the period, at least 1800 records were available at every single DIM.

Table 1

Statistical characteristics of the used data set

\begin{tabular}{lc}
\hline No. of records & 763505 \\
No. of animal with records & 88204 \\
No. of sires & 1209 \\
No. of dams & 68382 \\
No. of herds & 302 \\
No. of herd-test date & 18641 \\
No. of animal in pedigree & 168199 \\
No. of test-days per cow & 8.7 \\
Mean of milk yield (SD) & $29.67(7.09)$ \\
Mean of fat yield (SD) & $0.98(0.31)$ \\
Mean of protein yield (SD) & $0.91(0.22)$ \\
\hline
\end{tabular}

\section{Model}

Our intention was to determine the most suitable mathematical functions that described the lactation curve. But the computing resource required for obtaining a meaningful result with a large data size was not available. Therefore, twelve multitrait RRM with a smaller data size (100 679 TD) were employed. In finally, Legendre polynomial functions were chosen to fit the lactation curves in the framework of RRM for estimating (co)variance components. Finally, the model used in this research was the multitrait RRM. The model equation was:

$$
y_{i j k l m r}=y c_{i}+m t_{j}+h t d_{k}+\sum_{n=1}^{2} \beta_{l n} \varphi_{n r}(t)+\sum_{n=1}^{2} a_{m n} \varphi_{n r}(t)+\sum_{n=1}^{5} p e_{m n} \varphi_{n r}(t)+e_{i j k l m r}
$$

where $y_{i j k m r}$ is the observation of $r$-th trait, $y c_{i}$ is the fixed effect of $i$-th year of calving ( $i=1993$, $\ldots, 2010), m t_{j}$ is the fixed effect of $j$-th milking frequency $(j=2$ and 3$), h t d_{k}$ is the fixed effect of 
$k$-th herd-test date $(k=1, \ldots, 18641), \beta_{\text {ln }}$ is the $n$-th fixed regression coefficient specific to ageseason subclass $I(I=1, \ldots, 24), a_{m n}$ is the $n$-th random regression coefficient of additive genetic effect of cow $m, p e_{m n}$ is the $n$-th random regression coefficient of permanent environmental effect of cow $m, \varphi_{n r}(t)$ is the $n$-th coefficient of Legendre polynomials evaluated at DIM $t$ which is standardized between -1 and +1 , and $e_{i j k m r}$ is the random residual effect. Variance components were estimated with a Bayesian approach via the Gibbs sampling algorithm (by using the Gibbs3f90 software) as implemented by Misztal et al. (2002). A single chain of length 110000 was generated with the first 10000 regarded as the burn-in period. For all measures, heritabilities and correlations were calculated according to the formula given by Jakobsen et al. (2002).

\section{Measures of persistency}

Several different measures of persistency are currently in use worldwide. In this study the mean of peak milk yield ranged between $\mathrm{d} 50$ and $\mathrm{d} 100$. Therefore, the following measures were applied for describing persistency:

1. The difference of the lactation curve between $d 290$ and d 90 (Cobuci et al. 2007),

$$
P_{1}=\left(D I M_{290}-D I M_{90}\right)
$$

2. The average of the area under the lactation curve from d 225 to 305 as a deviation from the average of the area under the lactation curve from d 50 to 70 (Kistemaker 2003),

$$
P_{2}=\left(\frac{1}{51} \sum_{D I M=255}^{350} D I M_{i}-\frac{1}{21} \sum_{D I M=50}^{70} D I M_{i}\right)
$$

3. The area under the lactation curve from 11 to 100 subtracted from the area under lactation curve from d 101 to 200 (Jakobsen et al. 2002),

$$
P_{3}=\left(\sum_{D I M=101}^{200} D I M_{i}-\sum_{D I M=1}^{100} D I M_{i}\right)
$$

4. The area under the lactation curve from 11 to 100 subtracted from the area under lactation curve from d 201 to 300 (Jakobsen et al. 2002),

$$
P_{4}=\left(\sum_{D I M=201}^{300} D I M_{i}-\sum_{D I M=1}^{100} D I M_{i}\right)
$$

5. A summation of contribution for each day from d 61 to 280 as a deviation from $\mathrm{d} 60$ (Jamrozik et al. 1997),

$$
P_{5}=\sum_{D I M=61}^{280}\left(D I M_{i}-D I M_{60}\right)
$$

6. A summation of contribution for each day from d 60 to 279 as a deviation from d 280 (Jakobsen et al. 2002).

$$
P_{6}=\sum_{D I M=60}^{279}\left(D I M_{i}-D I M_{280}\right)
$$



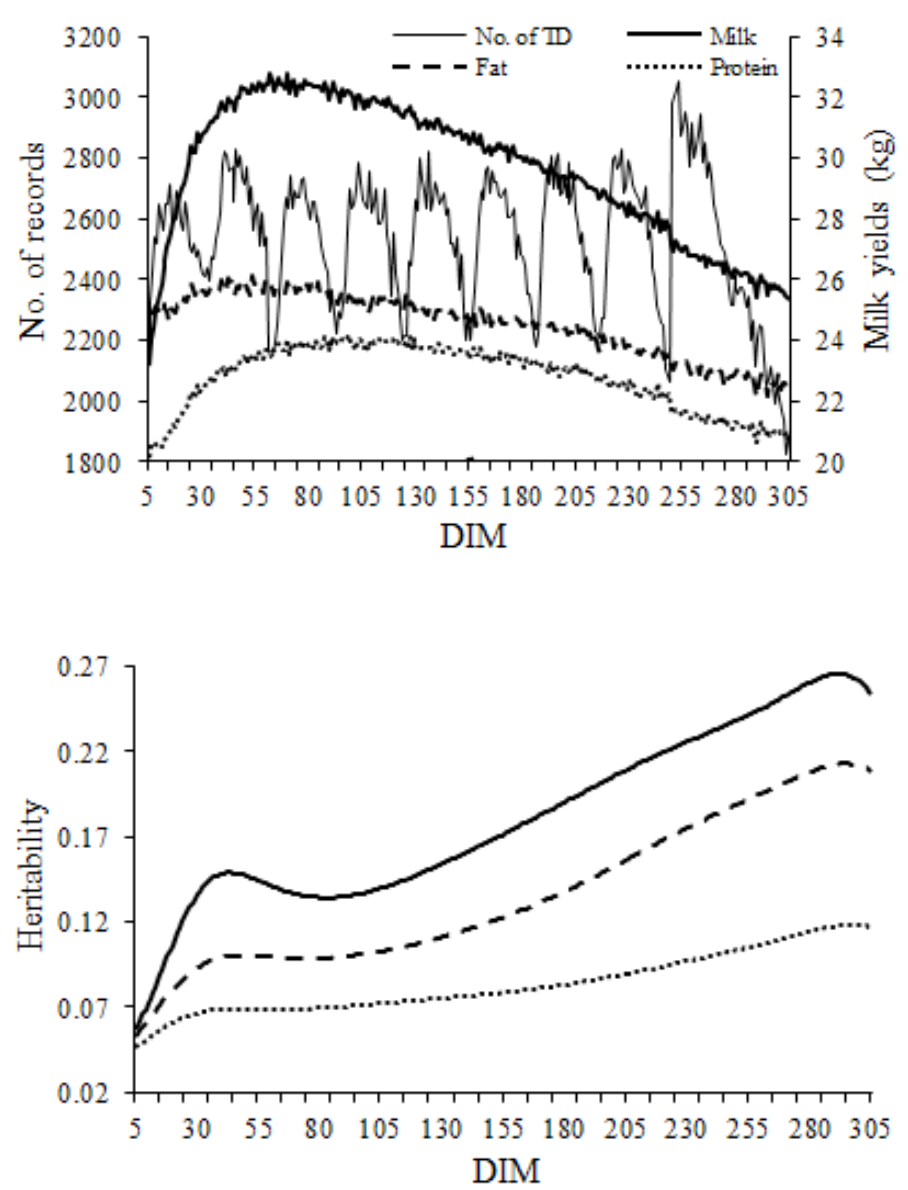

Figure 1

Distribution of TD records and of average daily milk yields at various lactation points from 5 to 305 days (Average for fat and protein yield multiplied by 25 )
Figure 2

Heritability estimates of test-day milk yield (solid line), fat yield (dotted line), and protein yield (dashed line)

\section{Results and discussion}

Daily milk production as a function of DIM is depicted in Figure 1. Peak production was lower and sooner for fat yield than milk yield, but persistency was higher for fat. Peak production was at $54 \mathrm{~d}$ for fat yield and at approximately $>60 \mathrm{~d}$ for milk and protein yield. For milk yield, mean TD was $29.67 \mathrm{~kg}$, with standard deviation of $7.09 \mathrm{~kg}$.

Heritability as a function of lactation stage was calculated as a ratio of genetic variance to total variance for milk, fat and protein TD yields and is shown in Figure 2. Similar to previous studies (Jakobsen et al. 2002, Muir et al. 2007), heritability for milk yield was higher than for fat and protein. For all traits, the heritability at the peak of lactation slightly decreased and subsequently increased reaching the highest in the end of lactation. The higher values of daily heritability at the end of lactation were mainly due to a decline in permanent environmental variance with DIM (results not shown). The increasing heritabilities for all traits in the end of lactation were consistent with results of Muir et al. (2007), whereas Jamrozik \& Schaeffer (1997) reported that the heritabilities were highest during the first $10 \mathrm{~d}$ of lactation for all traits. 
Graphic illustrations of genetic correlations between TD milk yields, TD fat yields, and TD protein yields at different stages of lactation are shown in Figure 3. As expected, for all traits the highest correlations were found for consecutive DIM, while the lowest were between yields at DIM early and late in lactation. These Figures indicate that genetic correlations between individual TD are alike for all traits. For milk and fat, however, genetic correlation coefficients were higher in comparison to protein yield, even when DIM were far apart. For instance, the genetic correlation between $\mathrm{d} 5$ and 305 was $0.47,0.47$ and 0.36 for milk, fat and protein yields respectively. Jakobsen et al. (2002) also reported positive genetic correlation with value above 0.40 for milk trait.

Heritabilities and correlations for six persistency measures (P1, P2, P3, P4, P5, P6), 305-d yield, and TD productions at d 20, 95, 155, and 290 after calving are in Table 2, 3, and 4 for milk, fat, and protein yield, respectively. In general, the heritability estimates obtained by different persistency measures were higher for protein yield $(0.05$ to 0.24$)$, followed by milk $(0.06$ to 0.22 ) and fat (0.02 to 0.17$)$. These results are not in accordance with the results obtained on the Danish population for milk production traits, in which heritabilities for persistency for fat yield were slightly higher than for milk and protein yield (Jakobsen et al. 2002). However, these estimates were comparable with $0.30,0.25$, and 0.28 obtained by Jamrozik et al. (1998) on Canadian Holstein cattle.

Heritabilities for $305-\mathrm{d}$ production of milk, fat, and protein $(0.31,0.29$, and 0.29$)$ were slightly higher than heritabilities for $305-d$ production estimated with a TD model $(0.27$ to $0.30,0.22$ to 0.30) (e.g., Muir et al. 2007, Lidauer \& Mäntysaari 1999), and lower than estimates of $0.42,0.37$, and 0.36 reported by Jakobsen et al. (2002). The heritability estimate for $305-d$ milk yield, however, was similar to those obtained by Khorshidie et al. (2012) on the same population used for this study.

Similar to previous studies (Jakobsen et al. 2002, Moradi Shahrbabak 1997), genetic correlations were high between the individual test-days and 305-d production and increased toward the middle of lactation. The permanent environmental correlations between the individual test-days and complete lactation were considerably lower than the respective genetic correlations ( 0.44 to 0.91 ).

Genetic correlations between persistency and the individual test-days for milk and protein yield were close to zero in the beginning of the lactation and as expected increasing in late lactation, which is a part of the persistency measures. Jakobsen et al. (2002) reported similar trend for Danish Holstein cows. The low genetic correlation between persistency measures at the first part of the lactation showed that selection based on the beginning of the lactation as a criterion for persistency would result in less persistent cows, with lower 305-d milk production (Moradi Shahrbabak 1997). The genetic correlation between 305-d production and persistency measures with the same sign (P1, P2, P3, P4, and P5) were higher for milk ( 0.41 to 0.55$)$ and protein yield $(0.50$ to 0.62$)$ than for fat yield $(0.20$ to 0.45$)$. Jamrozik et al. (1997) estimated genetic correlations between persistency and 305-d production for primiparous cows. They obtained genetic correlations of 0.10 to $0.55,0.06$ to 0.32 , and 0.32 to 0.57 for milk, fat, and protein yield, respectively. Their estimates were slightly lower than in the present investigation, but the same trend is seen with the highest genetic correlations between persistency and 305-d production of protein yield. The lowest rank correlation estimates between persistency of lactation and 305 - $d$ yield were obtained for P6, and agree 
with the results of Jakobsen et al. (2002) and Khorshidie et al. (2012). Cobuci et al. (2007) reported the genetic correlations for P6 with 305-d milk yield as -0.46 . Estimates of genetic correlations in the current investigation confirmed that there are weak genetic correlations between production and persistency measures, so that cows with the same milk production may present different levels of persistency of lactation (Cobuci et al. 2007, Jamrozik et al. 1998).
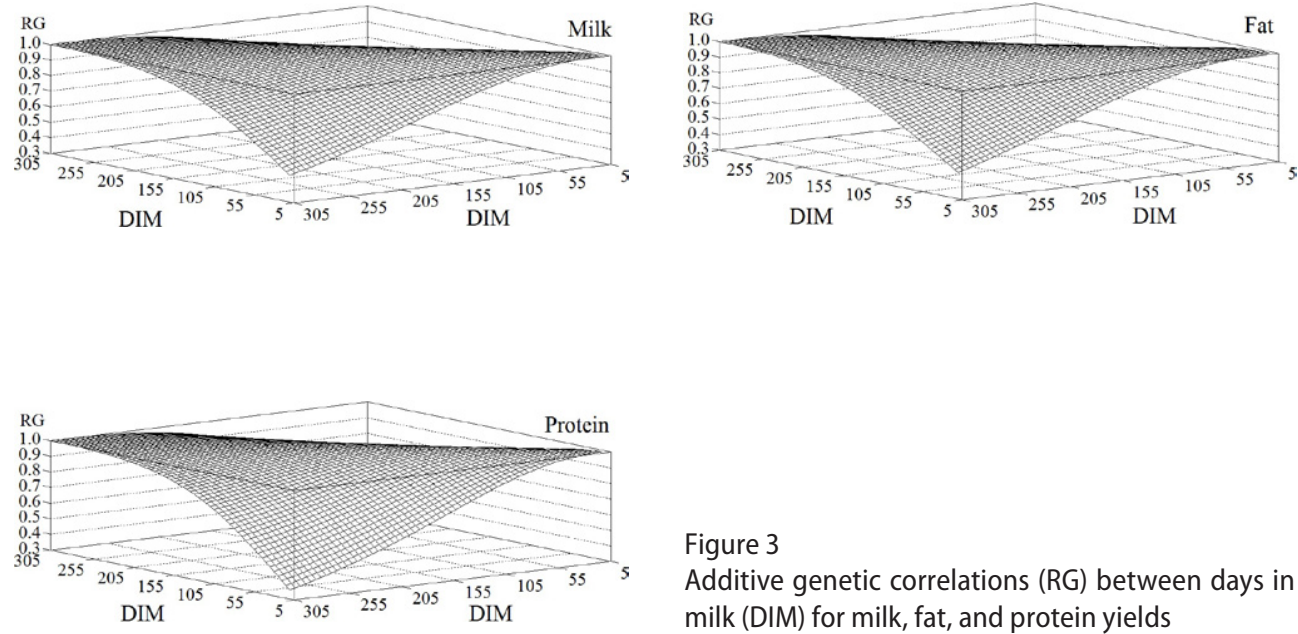

Figure 3

Additive genetic correlations (RG) between days in milk (DIM) for milk, fat, and protein yields

Table 2

Additive genetic (above diagonal) and environmental (below diagonal) correlations and heritabilities $\left(h^{2}\right)$ for six persistency measures (P1, P2, P3, P4, P5, P6), 305-d yield and TD production at day 20, 95, 155, and 290 for milk yield

\begin{tabular}{lcrcccccccccr}
\hline & $h^{2}$ & P1 & P2 & P3 & P4 & P5 & P6 & $305-d$ & 20 & 95 & 155 & 290 \\
\hline P1 & 0.08 & & 0.96 & 0.56 & 0.85 & 0.74 & -0.97 & 0.41 & -0.11 & 0.18 & 0.37 & 0.73 \\
P2 & 0.19 & 0.93 & & 0.78 & 0.97 & 0.90 & -0.86 & 0.49 & -0.20 & 0.27 & 0.50 & 0.76 \\
P3 & 0.08 & -0.14 & 0.23 & & 0.91 & 0.97 & -0.35 & 0.54 & -0.29 & 0.43 & 0.66 & 0.62 \\
P4 & 0.22 & 0.57 & 0.82 & 0.69 & & 0.98 & -0.70 & 0.55 & -0.23 & 0.37 & 0.60 & 0.76 \\
P5 & 0.07 & 0.50 & 0.77 & 0.74 & 0.88 & & -0.55 & 0.52 & -0.31 & 0.36 & 0.61 & 0.68 \\
P6 & 0.06 & -0.94 & -0.82 & 0.29 & -0.48 & -0.27 & & -0.33 & 0.02 & -0.10 & -0.23 & -0.66 \\
$305-d$ & 0.31 & -0.16 & -0.09 & 0.22 & 0.12 & 0.04 & 0.15 & & 0.64 & 0.97 & 0.98 & 0.92 \\
20 & 0.11 & 0.16 & -0.10 & -0.68 & -0.47 & -0.38 & -0.16 & 0.44 & & 0.94 & 0.83 & 0.56 \\
95 & 0.14 & -0.60 & -0.48 & 0.30 & -0.11 & -0.20 & 0.53 & 0.86 & 0.15 & & 0.97 & 0.80 \\
155 & 0.17 & -0.36 & -0.17 & 0.54 & 0.18 & 0.22 & 0.43 & 0.91 & 0.15 & 0.89 & & 0.92 \\
290 & 0.27 & 0.51 & 0.54 & 0.13 & 0.52 & 0.33 & -0.54 & 0.73 & 0.36 & 0.38 & 0.52 & \\
\hline
\end{tabular}


Table 3

Additive genetic (above diagonal) and environmental (below diagonal) correlations and heritabilities $\left(h^{2}\right)$ for six persistency measures (P1, P2, P3, P4, P5, P6), 305-d yield and TD production at day 20, 95, 155, and 290 for fat yield

\begin{tabular}{lcccccccccccr}
\hline & $h^{2}$ & P1 & P2 & P3 & P4 & P5 & P6 & 305-d & 20 & 95 & 155 & 290 \\
\hline P1 & 0.03 & & 0.93 & 0.27 & 0.75 & 0.53 & -0.97 & 0.45 & 0.08 & 0.17 & 0.32 & 0.79 \\
P2 & 0.15 & 0.93 & & 0.61 & 0.94 & 0.81 & -0.80 & 0.43 & -0.18 & 0.17 & 0.43 & 0.73 \\
P3 & 0.06 & 0.24 & 0.58 & & 0.84 & 0.96 & -0.02 & 0.20 & -0.61 & 0.12 & 0.48 & 0.23 \\
P4 & 0.17 & 0.70 & 0.90 & 0.81 & & 0.96 & -0.55 & 0.39 & -0.37 & 0.18 & 0.51 & 0.60 \\
P5 & 0.02 & 0.62 & 0.85 & 0.86 & 0.89 & & -0.29 & 0.27 & -0.54 & 0.12 & 0.48 & 0.41 \\
P6 & 0.02 & -0.89 & -0.72 & 0.07 & -0.51 & -0.25 & & -0.43 & -0.26 & -0.16 & -0.22 & -0.76 \\
$305-d$ & 0.29 & -0.11 & -0.10 & 0.03 & -0.01 & -0.04 & 0.11 & & 0.65 & 0.96 & 0.94 & 0.90 \\
20 & 0.06 & -0.11 & -0.35 & -0.67 & -0.57 & -0.47 & 0.05 & 0.59 & & 0.95 & 0.85 & 0.55 \\
95 & 0.07 & -0.52 & -0.46 & -0.02 & -0.25 & -0.32 & 0.41 & 0.87 & 0.40 & & 0.97 & 0.78 \\
155 & 0.08 & -0.17 & 0.00 & 0.41 & 0.18 & 0.25 & 0.32 & 0.90 & 0.31 & 0.81 & & 0.91 \\
290 & 0.12 & 0.49 & 0.47 & 0.17 & 0.44 & 0.27 & -0.52 & 0.76 & 0.32 & 0.48 & 0.62 & \\
\hline
\end{tabular}

Table 4

Additive genetic (above diagonal) and environmental (below diagonal) correlations and heritabilities $\left(h^{2}\right)$ for six persistency measures (P1, P2, P3, P4, P5, P6), 305-d yield and TD production at day 20, 95, 155, and 290 for protein yield

\begin{tabular}{lcrrrrrrrrrrr}
\hline & $h^{2}$ & P1 & P2 & P3 & P4 & P5 & P6 & $305-d$ & 20 & 95 & 155 & 290 \\
\hline P1 & 0.07 & & 0.97 & 0.56 & 0.88 & 0.77 & -0.98 & 0.50 & 0.00 & 0.24 & 0.42 & 0.81 \\
P2 & 0.21 & 0.93 & & 0.75 & 0.97 & 0.90 & -0.90 & 0.57 & -0.09 & 0.32 & 0.53 & 0.83 \\
P3 & 0.09 & -0.11 & 0.27 & & 0.89 & 0.96 & -0.40 & 0.58 & -0.23 & 0.46 & 0.69 & 0.64 \\
P4 & 0.24 & 0.62 & 0.86 & 0.67 & & 0.98 & -0.78 & 0.62 & -0.13 & 0.40 & 0.63 & 0.82 \\
P5 & 0.05 & 0.42 & 0.72 & 0.82 & 0.88 & & -0.63 & 0.58 & -0.22 & 0.40 & 0.64 & 0.74 \\
P6 & 0.05 & -0.94 & -0.79 & 0.32 & -0.48 & -0.15 & & -0.44 & -0.06 & -0.18 & -0.32 & -0.76 \\
$305-d$ & 0.29 & -0.07 & 0.01 & 0.23 & 0.17 & 0.13 & 0.09 & & 0.65 & 0.96 & 0.98 & 0.92 \\
20 & 0.08 & 0.09 & -0.16 & -0.65 & -0.45 & -0.45 & -0.15 & 0.48 & & 0.92 & 0.77 & 0.46 \\
95 & 0.10 & -0.52 & -0.41 & 0.28 & -0.10 & -0.11 & 0.47 & 0.86 & 0.25 & & 0.96 & 0.77 \\
155 & 0.12 & -0.31 & -0.09 & 0.58 & 0.22 & 0.34 & 0.42 & 0.89 & 0.16 & 0.88 & & 0.92 \\
290 & 0.21 & 0.61 & 0.61 & 0.10 & 0.56 & 0.31 & -0.61 & 0.72 & 0.36 & 0.36 & 0.46 & \\
\hline
\end{tabular}

Genetic correlations at different stages of lactation between TD milk production traits varied from 0.23 to 0.90 , although most estimates were moderate to high (Figure 4). The highest correlation was between milk and protein, whereas the correlation between milk and fat was the lowest. These graphs indicate that genetic correlations between different yield traits depend on the interval between tests and on whether they are recorded at the same stage of lactation or not. Therefore, the highest genetic correlation was observed between the same DIM, usually about 0.65 to 0.90 (see Figure 5 for details). Jakobsen et al. (2002) found estimates of 0.22 to 0.66 between milk and fat, and 0.82 to 0.90 between milk and protein. As in the case of genetic correlations within traits, genetic correlations between traits decrease as DIM got further apart. However the strength of the correlations decreased with increasing DIM, especially between milk and fat. 

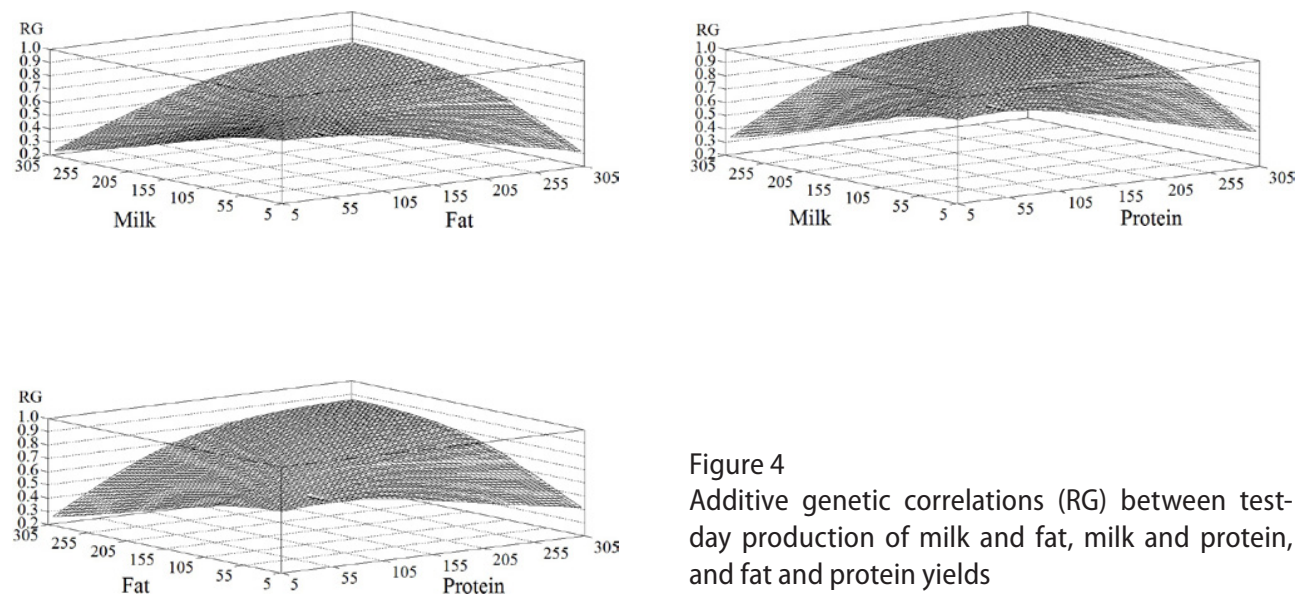

Figure 4

Additive genetic correlations (RG) between testday production of milk and fat, milk and protein, and fat and protein yields

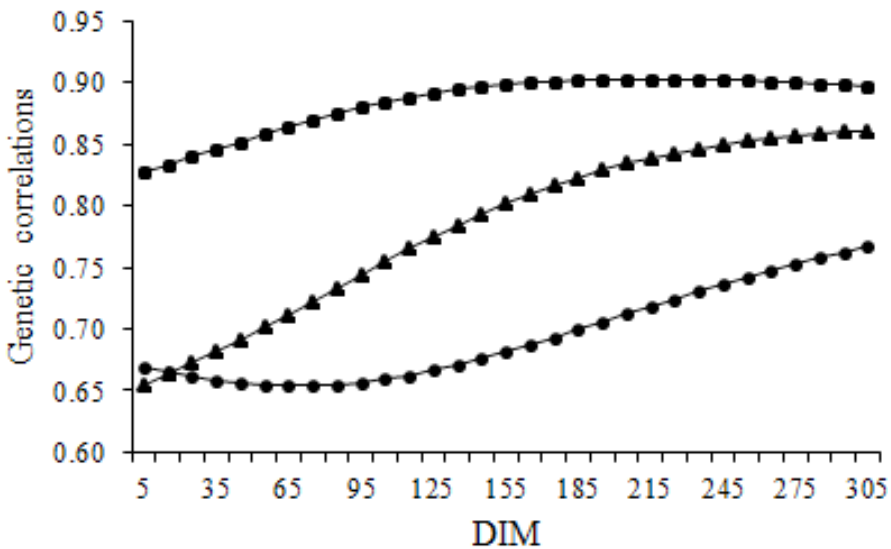

Figure 5

Additive genetic correlations for milk and fat (circle), milk and protein (square), fat and protein yield (triangular) in different DIM

The estimated genetic and permanent environmental correlations, respectively, between persistency measures for milk and fat and for milk and protein are given in Tables 5 and 6 . Also included in Tables 5 and 6 are correlations between persistency and 305-d yield for milk and fat, and for milk and protein, as well as correlations between 305-d yield of milk and fat and between milk and protein. Genetic correlations between persistency measures and $305-\mathrm{d}$ yield were moderate to high, as expected; and were considerable higher than the respective environmental correlations. As shown in Table 5, the correlation of the same persistency measures between milk and fat yields averaged 0.76 , and between milk and protein yields averaged 0.82 . 
The genetic correlations between 305- $d$ yield of milk and fat, and milk and protein were 0.68 and 0.90 , respectively. The genetic correlation between milk and fat is slightly different from earlier investigations by Kheirabadi et al. (2013) they found estimates of genetic correlations of $0.75,0.92$, and 0.83 for milk yields of Iranian Holstein. Large genetic correlation between milk and protein yield than between milk and fat yield was reported also by Jakobsen et al. (2002) and Weller et al. (2006).

Table 5

Additive genetic correlations between persistency measures (P1, P2, P3, P4, P5, P6) and 305-d yield for milk, fat, and protein

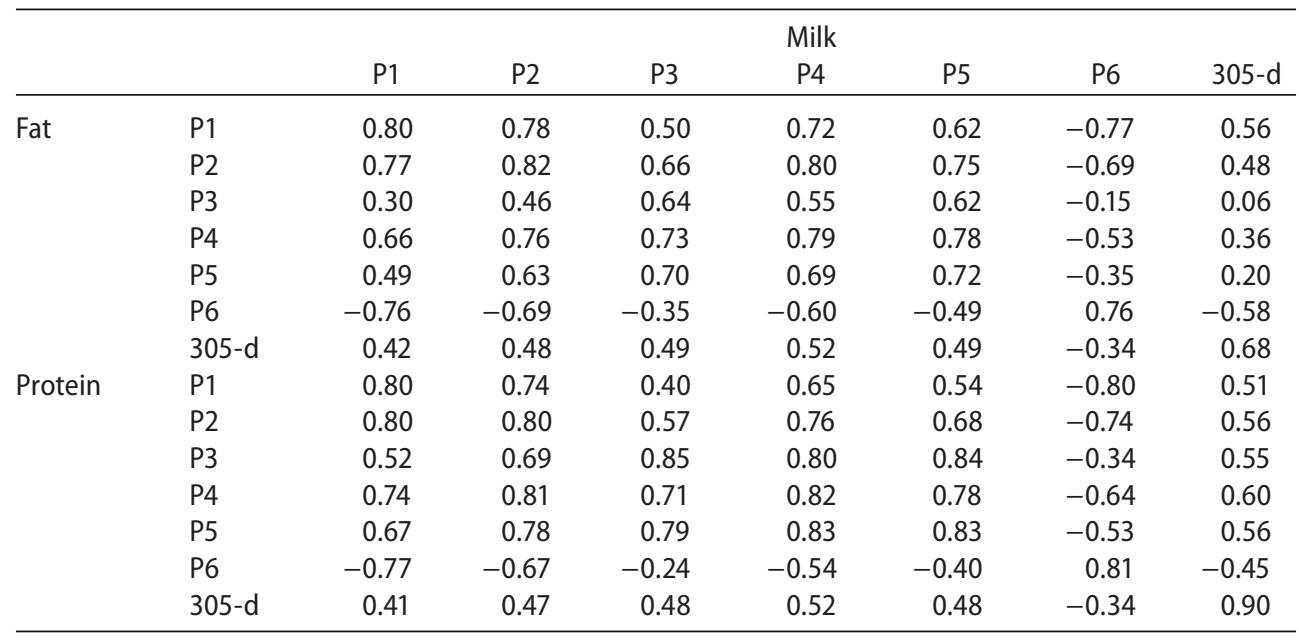

Table 6

Environmental correlations between persistency measures (P1, P2, P3, P4, P5, P6) and 305- $d$ yield for milk, fat, and protein

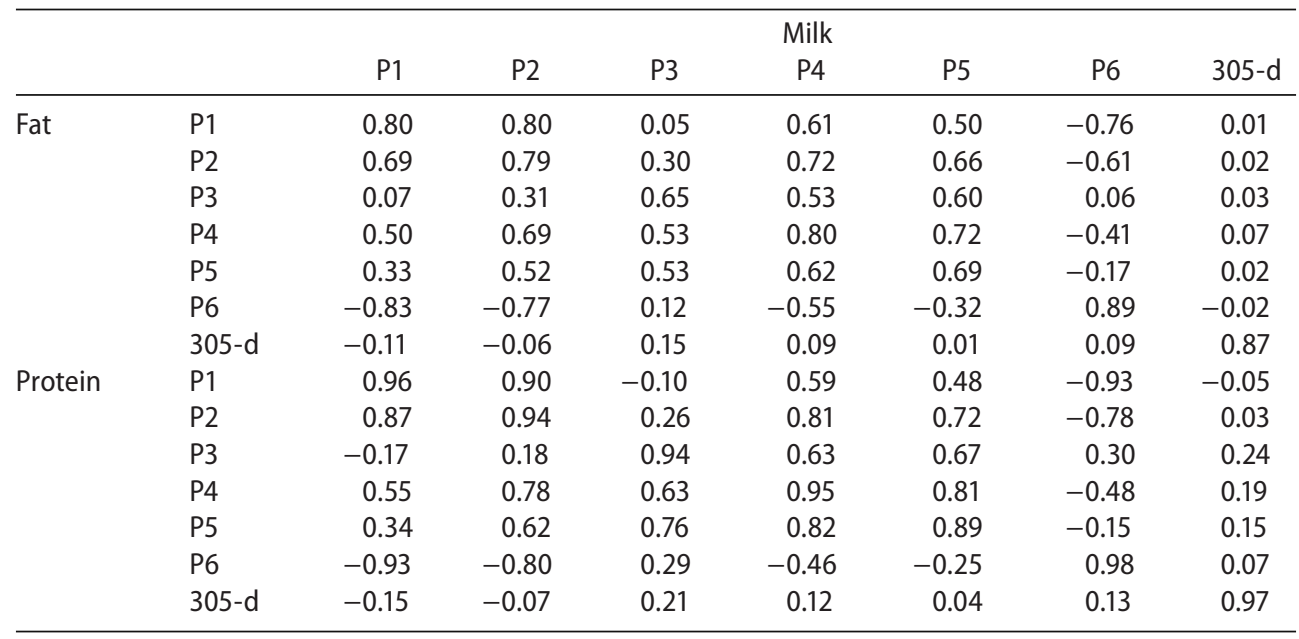


In this research six selection criteria were compared. Genetic correlations for the same persistency between traits were all $>0.5$. As showed and discussed above, persistency of yield traits is moderately heritable, but considerably related to the total 305-d production, thus doesn't allowing for efficient selection for the shape of lactation curve. However when comparing the six persistency measures in the present study, although P6 behaved as an independent measure from milk productions, $\mathrm{P} 4$ had higher heritability than P6 and thus it is suggested for measuring persistency under conditions in Iran.

\section{Acknowledgements}

The authors would like to thank the Iranian Animal Breeding Center for providing data. The first author also thanks to Dr. A.A Shadparvar for many helpful suggestions during development of this investigation.

\section{References}

Cobuci JA, Euclydes RF, Costa CN, Torres RA, Lopes PS, Pereira CS (2007) Genetic evaluation for persistency of lactation in Holstein cows using a random regression model. Genet Mol Biol 30, 349-355

Dekkers JCM, Ten Hag JH, Weersink A (1998) Economic aspects of persistency of lactation in dairy cattle. Livest Prod Sci 53, 237-252

Gengler N (1996) Persistency of lactation yields: a review. Interbull Bull 12, 87-96

Harder B, Bennewitz J, Hinrichs D, Kalm E (2006) Genetic Parameters for Health Traits and Their Relationship to Different Persistency Traits in German Holstein Dairy Cattle. J Dairy Sci 89, 3202-3212

Jakobsen JH, Madsen P, Jensen J, Pedersen J, Christensen LG, Sorensen DA (2002) Genetic Parameters for Milk Production and Persistency for Danish Holsteins Estimated in Random Regression Models using REML. J Dairy Sci 85, 1607-1616

Jamrozik J, Schaeffer LR (1997) Estimates of Genetic Parameters for a Test Day Model with Random Regressions for Yield Traits of First Lactation Holsteins. J Dairy Sci 80, 762-770

Jamrozik J, Schaeffer LR, Dekkers JCM (1997) Genetic Evaluation of Dairy Cattle Using Test Day Yields and Random Regression Model. J Dairy Sci 80, 1217-1226

Jamrozik J, Jansen G, Schaeffer LR, Liu Z (1998) Analysis of Persistency of Lactation Calculated from a Random Regression Test Day Model. Interbull Bull 17, 64-69

Kadarmideen HN, Thompson R, Coffey MP, Kossaibati MA (2003) Genetic parameters and evaluations from single- and multiple-trait analysis of dairy cow fertility and milk production. Livest Prod Sci 81, 183-195

Kheirabadi K, Alijani S, Zavadilová L, Rafat SA, Moghaddam G (2013) Estimation of genetic parameters for daily milk yields of primiparous Iranian Holstein cows. Arch Tierz A44, doi: 10.7482/0003-9438-56-044

Khorshidie R, Shadparvar AA, Ghavi Hossein-Zadeh N, Joezy Shakalgurabi S (2012) Genetic trends for 305-day milk yield and persistency in Iranian Holsteins. Livest Sci 144, 211-217

Kistemaker GJ (2003) Comparison of Persistency Definitions in Random Regression Test Day Models. Interbull Bull 30, 96-98

Lidauer M, Mäntysaari EA (1999) Multiple Trait Reduced Rank Random Regression Test-Day Model for Production Traits. Interbull Bull 22, 74-80

Misztal I, Tsuruta S, Strabel T, Auvray B, Druet T, Lee DH (2002) BLUPF90 and related programs (BGF90). In: Proc 7th WCGALP, Montpellier, France, Session 28:07

Moradi Shahrbabak M (1997) Studies of random regression test day models and persistency for Iranian Holstein production traits. PhD thesis, University of Guelph, Guelph, ON, Canada 
Muir BL (2004) Genetics of lactation persistency and relationships with reproductive performance in Holsteins. PhD thesis, University of Guelph, Guelph, ON, Canada

Muir BL, Kistemaker G, Jamrozik J, Canavesi F (2007) Genetic Parameters for a Multiple-Trait Multiple-Lactation Random Regression Test-Day Model in Italian Holsteins. J Dairy Sci 90, 1564-1574

Sölkner J, Fuchs W (1987) A comparison of different measures of persistency with special respect to variation of test-day milk yields. Livest Prod Sci 16, 305-319

Swalve HH, Gengler N (1999) Genetic of lactation persistency. Br Soc Anim Sci Occ Publ 24, 75-82

Togashi K, Lin CY (2004) Efficiency of Different Selection Criteria for Persistency and Lactation Milk Yield. J Dairy Sci 87, 1528-1535

Weller Jl, Ezra E, Leitner G (2006) Genetic Analysis of Persistency in the Israeli Holstein Population by the Multitrait Animal Model. J Dairy Sci 89, 2738-2746 